Щур Наталія Олегівна кандидат наук 3 державного управління, доцент кафедри суспільного розвитку і суспільно-владних відносин Національної академії державного управління при Президентові України, вул. Антона Цедіка, 20, м. Київ, 03057, тел.: (096) 376-55-07, e-mail: natashchur@ukr.net, https://orcid.org/0000-0002-7648-7893

\title{
ГЛОКАЛІЗАЦЙНІ ПРОЦЕСИ ЕКОНОМІЧНОЇ ТА КУЛЬТУРНОЇ СФЕРИ ЯК БАЗИС СУСПІЛЬНОГО РОЗВИТКУ
}

Анотація. У статті розглянуто окремі аспекти структурних змін в українському суспільстві, які торкаються культурно-цивілізаційних змін суспільного життя, соціально-економічної сфери, виникаючи в нових умовах глокалізації.

Суспільне життя відбувається в трьох основних сферах, або реальних процесах життєдіяльності, - в матеріально-економічній, соціально-політичній і духовно-культурній. Визначення трьох основних сфер суспільного життя певною мірою має відносний, умовний характер, тому що реальна людська життєдіяльність - це тісний взаємозв'язок і взаємовплив цих сфер. Абсолютизація якоїсь однієї сфери суспільного життя веде до створення деформованої моделі суспільства.

Суспільство як єдність соціального i індивідуального спрямоване на забезпечення умов для збереження та суспільного розвитку, на забезпечення умов для реалізації і розвитку здібностей громадян, для задоволення ними своїх потреб. Основні сфери людської життєдіяльності зумовлюють основні функції суспільства: забезпечення і відтворення матеріально-економічних умов життя (зростання добробуту, матеріального достатку); регулювання i організацію суспільних відносин (соціально-політичні, етичні гарантії виживання людства, упорядкування і нормалізацію політичних, правових, моральних відносин); духовно-культурний розвиток суспільства. Здійснено аналіз тенденцій розвитку економічної функції в період переходу до ринкових відносин, а також поєднання адміністративних та економічних методів управління економічними процесами.

Сучасний світ динамічно змінюється під впливом науково-технічної та інформаційної революції. Новим, інноваційним змістом наповнюються всі сфери суспільного життя. Відповідно, набуває нових ознак усталений плин глобального життя, переформатовується його устрій. 3'ясовано сутність культури як умови реалізації багатовимірності людини в умовах поглиблення глобальних викликів сучасності, що представляють собою основу для виявлення міжцивілізаційного спілкування і діалогу.

Ключові слова: глокалізація, економічні процеси, відтворення, розвиток, адміністративні та економічні методи, галузь культури, культурна політика, трансформаційний процес. 
Shchur Nataliia Olehivna PhD in Public Administration, Associate Professor of the Department for Social Development and Public and Governance Relations of the National Academy for Public Administration under the President of Ukraine, 03057, Anton Tsedik Str., 20, Kyiv, 03057, tel.: (096)3765507, e-mail: natashchur@ukr.net, https//orcid.org/0000-0002-7648-7893

\section{GLOCALIZATION PROCESSES OF THE ECONOMIC AND CULTURAL SPHERE AS A BASIS OF SOCIAL DEVELOPMENT}

Abstract. The article considers some aspects of structural changes in Ukrainian society, which affect the cultural and civilizational changes in public life, socioeconomic sphere, arising in new conditions - glocalization.

Public life takes place in three main spheres, or real processes of life - in the material-economic, socio-political and spiritual-cultural. The definition of the three main spheres of social life to some extent has a relative, conditional nature, because real human life - is a close relationship and interaction of these areas. Absolutization of any one sphere of social life leads to the creation of a deformed model of society.

Society as a unity of social and individual is aimed at providing conditions for preservation and social development, to provide conditions for the realization and development of citizens' abilities, to meet their needs. The main spheres of human life determine the main functions of society: the provision and reproduction of material and economic living conditions (growth of welfare, material prosperity); regulation and organization of social relations (socio-political, ethical guarantees of human survival, streamlining and normalization of political, legal, moral relations); spiritual and cultural development of society. The analysis of tendencies of development of economic function in the period of transition to market relations, and also a combination of administrative and economic methods of management of economic processes is carried out.

The modern world is changing dynamically under the influence of the scientific, technological and information revolution. All spheres of public life are filled with new, innovative content. Accordingly, the established course of global life acquires new features, its structure is reformatted. The essence of culture as a condition for the realization of human multidimensionality in the context of deepening global challenges of today, which are the basis for the identification of intercivilizational communication and dialogue.

Keywords: glocalization, economic processes, reproduction, development, administrative and economic methods, branch of culture, cultural policy, transformation process.

Постановка проблеми. Глобальне суспільство входить у нову історичну епоху, однією з відмінних ознак якої $\epsilon$ стрімке наростання глокальних трансформацій - процесів, що складають зміст так званої «глокалізації» та гібридизації, які за своєю природою є об'єктивними чинниками, що призводять як до позитивних якісних та кількісних зрушень. За таких умов важливим є розуміння 
нових явищ, щоб визначити раціональну й ефективну стратегію держави, регіональних міждержавних альянсів та світового співтовариства загалом.

Трансформаційні зміни в економіці вимагають від держави нових підходів, методів та інструментів регулювання економіки. Для забезпечення гармонізації національної та глобальної економіки уряд країни повинен розробити стратегію ефективного входження України у глобальний світ.

На даному етапі розвитку сучасного українського суспільства культура може посідати декілька стратегічних позицій. По-перше, вона є одним 3 інструментів євроінтеграції. Розвиваючи сектор культурних індустрій, модернізуючи культурну політику і вдосконалюючи механізми їі впровадження, можливо окреслити вимір успішної зовнішньої політики та наблизити нашу країну до омріяних європейських стандартів. По-друге, досвід європейських країн показує важливість участі культурного сектору в розбудові громадянського суспільства та економічному зростанні держави, тобто у внутрішньополітичному житті країни в умовах культурної глокалізації.

У нових умовах реформування українського суспільства нагальним питанням $\epsilon$ вивчення трансформаційних процесів, які відбуваються і пов'язані з новими умовами глокалізаційних змін, тому що ці зміни торкаються всіх основ життєдіяльності суспільства. В цьому сенсі треба розглядати проблеми структуризації українського суспільства, що зумовлено формуванням нових суспільних відносин.

Аналіз останніх досліджень і публікацій. Основні особливості та специфіка процесів модернізації та процесів, які торкаються змін в українському суспільстві щодо глокалізації та проблем, які виникають у структурі суспільства, досліджують Е.Гідденс, Р.Робертсон і М.Кастельс, М.Осійчук та ін.

Потреба в нових цінностях суспільства, про яку останнім часом все більше говорять в Україні, стає визначальною для розвитку країни. Все очевиднішою стає також необхідність розробки і впровадження інклюзивної культурної політики, яка визначатиме як напрямки розвитку саме культурної царини та створюватиме загальні рамки для трансформації суспільства на національному, регіональному та місцевому рівнях. Питання державної політики в сфері культури відображені в роботах таких авторів як Т.Абанкіна, Ю.Богуцький, В.Трощинський, Г.Дутчак, М.Жулинський, В. Кремень, О.Немчук, В.Петренко, О.Семашко, В. Шейко, Л.Яковенко та інших. Актуальні питання державної політики в сфері в Україні досліджують В.Андрущенко, І.Бех, М.Бурда, В.Друзь, С. Красняков, Л.Шевченко та інші.

Мета статті - розгляд окремих аспектів змін в суспільстві в економічних i культурних сферах у процесі глокалізаційних перетворень, проблем структурноцивілізаційного вибору, які відбуваються у сучасному трансформаційному суспільстві.

Виклад основного матеріалу. Початок XXI століття знаменується суперечливою та складною тенденцію до глокалізаційних процесів, які значно посилили вплив на трансформацію соціальної структури суспільства. Реалії сучасного життя потрібно розглядати в новому контексті теорії модернізації, яка вивчає моделі та варіанти наближення традиційних суспільств до сучасних норм та 
стандартів. Процес глокалізації переводить модернізацію на локальний рівень i позбавляє іï єдиного зразка, бо класичне розуміння цього процесу є надто жорстким. Воно вимагає взаємозв'язку всіх параметрів, що відбуваються під час переходу від традиційного до сучасного суспільства.

В працях українських вчених теорія модернізму набуває популярності. При цьому багато дослідників зазначають, що модернізаційні процеси в Україні не мають певної спрямованості, тобто залишається невирішеним питання про мету та кінцевий образ цих змін. Тому однією 3 важливих $є$ проблема політичної модернізації, що являє собою особливий специфічний напрямок модернізації й водночас забезпечення процесу в цілому в сфері владних відносин [1, с. 30], але ж саме вони мають великий вплив на решту сфер суспільного життя.

Сьогодні суспільство потребує нових орієнтирів реальної модернізації, тому зрозуміло, що кожен народ вибирає свій спосіб руху, спираючись на цивілізаційний досвід та на власні історичні надбання. В сучасний період для нашого суспільства характерна наздоганяюча модель модернізації, метою якої $\epsilon$ створення ринкового, демократичного громадянського суспільства [2, с. 106].

Процеси, що відбуваються в нашому суспільстві, кваліфікуються як трансформаційні як за своєю суттю, так і за своєю спрямованістю. Вони виявляють низку проблем,серед яких проблема структурно-цивілізаційного вибору, відповідність модернізаційним та культурно-історичним перетворенням. Специфіку сучасного періоду в історії українського суспільства становлять зміни соціальної структури. Проблеми змін відзначаються в економічній, соціальній, державній, культурній сферах, де виникають нетривкі та аморфні форми. Тому постає питання про необхідність з боку суспільства зважитися на певний варіант структурного вибору. Зваженим кроком структурної перебудови разом 3 автономізацією окремих сфер повинні стати зміни фундаментального принципу щодо побудови суспільства як держави i створення нових інституцій громадянського суспільства.

Сучасні процеси трансформації у суспільстві можна кваліфікувати як пошук якісно іншого, нового шляху розвитку. Головною метою на даному етапі змін в нашому суспільстві стає призупинення подальшого розхитування системи. Досягти мети старими методами і способами неможливо, тому деякі перетворення мають руйнівну орієнтацію, що інколи завдає шкоди процесам реформування. Саме нові засоби дій реформаторів-практиків постають сьогодні як дуже важлива обставина, часом навіть більш важлива, ніж конкретні практичні кроки. Розглядаючи провідні орієнтири реформаторської діяльності, необхідно прагнути до суттєвого підвищення рівня цивілізованості. Трансформація суспільства у межах соціокультурної площини має полягати у визначенні своєї ідентичності, самобутності, подолання аморфності в соціумі [3, с. 123].

Важливою ознакою трансформаційних процесів у суспільстві є можливість у кожного індивіда підвищити свій соціальний статус, посилення мобільності населення. В той же час зміна соціального статусу супроводжується процесами маргіналізації, на жаль, процес зміни соціально-економічного статусу нерідко супроводжується переходом у нижчі верстви населення. Важливим напрямком трансформаційних змін $є$ становлення ринку праці,підвищення престижу 
освіти,посилення ролі культурного фактора у формуванні високостатусних груп, значна роль у цьому процесі належить творчій еліті [4, с. 291]. Зміни, що відбуваються в соціумі, потребують значну увагу приділяти діям влади. Тому зміни форм влади в сучасному глобальному суспільстві віддзеркалюються у трансформаціях суверенітету сучасної держави [5, с. 46]. Втім, зміни почалися і для істотної, більш глибокої трансформації структури суспільства необхідне системне перетворення владних інститутів [6, с. 76].

Економіка України переважну частину XX ст. розвивалась як економічна система централізовано-планового типу. Трансформаційні зміни в умовах формування ринкової економіки кардинально змінює роль держави в економічних відносинах. Сьогодні, коли відмирає всеосяжне централізоване планування, роль держави зводиться до виконання таких функцій, як: здійснення законодавчого регулювання основ економічної, господарської діяльності; контроль за дотриманням встановлених законом правил економічної та господарської діяльності, захист відносин, що виникають у зв’язку з цими правилами, та прав їх учасників; забезпечення соціальної спрямованості економіки.

Державне регулювання економічними процесами зумовлюється самою сутністю держави як інституту, покликаного відображати загальну волю та інтереси більшості населення. Для забезпечення гармонізації національної та глобальної економіки держава вже тепер повинна розробити стратегію ефективного входження України у глобальний світ, яка має базуватися на поєднанні принципів відкритості економіки із захистом внутрішнього ринку, аналізі державних, регіональних та галузевих концепцій і програм соціальноекономічного розвитку в поєднанні із загальною ситуацією на світовому ринку та перспективами інтеграції України у світову економіку. Ефективність виконання державою своїх економічних функцій залежить від сукупності об'єктивних i суб'єктивних факторів. Основними серед них є рівень розвитку економічних відносин, що виступає основою ефективного функціонування держави; розвиток соціальної сфери суспільства; ступінь демократичності політичного життя суспільства.

Світовий досвід показує, що економічна кон'юнктура у країнах з ринковою економікою зазнає коливань. Періодично виникають порушення економічної рівноваги, безробіття та інфляція. Усе це не в змозі подолати саморегулюючий ринковий механізм. Тому держава здійснює функцію стабілізації економічної кон'юнктури, впливаючи на економічну активність через заходи монетарної та фіскальної політики, розробку різного роду програм, спрямованих на регулювання певних сфер економіки. Широко використовуються заходи впливу на грошовий обіг, що дозволяють регулювати грошову масу в обігу і через неї впливати на економічну діяльність. Цій меті слугують і фіскальні заходи - оподаткування, субсидії і субвенції. Через них регулюється платоспроможний попит суб'єктів економічної діяльності, рівень їх економічної активності. Широко використовується програмування. Суть його в обгрунтуванні програм розвитку як економіки в цілому, так і окремих галузей, в яких визначаються певні цілі та засоби їх досягнення. Такі програми розробляються державними органами і носять 
рекомендаційний характер. Суб’єкти економічної діяльності використовують їх як важливе джерело інформації про тенденції економічного розвитку.

Слід зазначити, що інновації переборюють економічну депресію і є головною умовою до пожвавлення й підйому світової економіки - це загальна закономірність економічної динаміки. Від того, коли і як буде розроблена й реалізована інвестиційна стратегія технологічного прориву, залежить тривалість і наслідки економічних криз. Тільки на основі передових наукових досліджень і створення високих технологій можна забезпечити подолання економічної відсталості й бідності в багатьох країнах, що розвиваються, і звести до мінімуму наслідки економічних криз.

На основі аналізу тенденцій розвитку економічної функції в період глокальних змін можна виділити основні риси, характерні на даному етапі розвитку держави: пошук співвідношення державного регулювання економіки та саморегулювання, а також визначення нових меж втручання держави в економіку держави; зростання ролі саморегулювання економікою; визначення оптимального рівня централізації та децентралізації в управлінні економікою; подальше вдосконалення форм непрямого впливу на економіку держави; різке збільшення нових ринкових інститутів; пошук найбільш раціонального поєднання адміністративних та економічних методів управління економічними процесами; вдосконалення економічної політики держави на науковій основі з урахуванням особливостей розвитку держави; вдосконалення правових форм реалізації економічного механізму; врахування інших факторів, що здійснюють прямий вплив на економіку держави.

Розвиток економічної функції сучасної держави тісно пов'язаний 3 їі інвестиційною активністю. Однією з найвагоміших причин стримування переходу української економіки до стадії економічного зростання на засадах структурного та якісного оновлення народного господарства $\epsilon$ низька інвестиційна активність. Саме через неї значно прискорюються процеси морального та фізичного старіння матеріально-технічної бази суспільного виробництва, посилюється структурна диспропорційність, знижується ефективність використання економічних ресурсів. Водночас мультиплікаційний механізм, приведений у дію систематичним зменшенням інвестиційних вкладень у національну економіку, прискорює спад виробництва, що у свою чергу розмиває економічну та соціальну базу реформ, скорочує інвестиційний потенціал та послаблює мотивацію інвестиційної поведінки суб'єктів економічних відносин [7, с. 38].

Тривале збереження та посилення регресивних тенденцій - це сигнал для критичного переосмислення стратегії i тактики реформування, переорієнтації економічної функції держави та посилення уваги до фундаментальних відтворювальних процесів. Перш за все процесів відтворення основного капіталу, які протягом останнього часу вийшли з-під сфери ефективного економічного регулювання, в тому числі й внаслідок недосконалої інвестиційної політики держави.

Свроінтеграція України є закономірним процесом, зумовленим європейським вибором нашої держави, ii відкритістю до міжкультурного діалогу та наявним великим творчим потенціалом. 
Приєднання України до грантової програми ЄС «Креативна Європа» відповідну угоду було підписано в листопаді 2015 року. А 3 лютого 2016 року Верховна Рада України ухвалила Закон України «Про ратифікацію Угоди між урядом України та Європейською Комісією про участь України у програмі «Креативна Європа»: програма Європейського Союзу для сектора культури та креативності, та про співробітництво між Україною та Свропейським Союзом у підпрограмі «Медіа» програми «Креативна Європа». Ратифікація документа створила передумови для участі України в одній з найвагоміших програм ЄС культурно-гуманітарного спрямування, що представляє нашій країні додаткові стимули й можливості, зокрема фінансові, для розвитку національної галузі культури та креативних індустрій, заохочує тісне співробітництво між культурними інституціями різних країн Європи, створюючи таким чином підгрунтя для повноцінної інтеграції України в європейський гуманітарний простір.

Співпраця в рамках цієї програми триватиме до 2020 року. Наразі розпочато практичний етап реалізації проекту COMUS - спільного проекту Ради Європи i Європейської Комісії «Урбаністичні стратегії в історичних містах, скеровані громадянами», який передбачає комплексну взаємодію органів влади всіх рівнів i місцевих громад 3 метою покращення теперішнього міського середовища невеликих історичних міст, зупинення деградації історичного середовища та заохочення місцевих мешканців до активної участі в процесі прийняття рішень i розроблення стратегії розвитку міста з акцентом на об'єкти культурної спадщини. Пілотними містами проекту обрано Жовклу, що на Львівщині, Прилуки Чернігівської області та обласний центр Волині - Луцьк [8; 9].

Інший проект у рамках програми «Культура і креативність», Сайт «Культура i Креативність» був створений 2015 року в рамках програми ЄС для підтримки внеску культури в соціально-економічний розвиток шести країн Східного партнерства: Вірменії, Азербайджану, Білорусі, Грузії, Молдови й України. Це науково-дослідницька та пропагандистська ініціатива ЮНЕСКО, покликана, зокрема, допомогти людям i громадам у питаннях розширення можливостей життєвого вибору й адаптації до змін, передбачає розробку певної системи показників, які висвітлюють дані щодо рівня впливу культурного сектора на національне економічне зростання [9; 10]. За час свого існування сайт набув популярності i став корисним ресурсом для представників культурних i креативних індустрій. Відколи Програма СС припинила свою роботу, сайт працює за підтримки Британської Ради.

Беручи до уваги активну підтримку Україною європейського вектора гуманітарного розвитку, перед культурною спільнотою постає багато питань, зокрема, що таке «європейські стандарти», які особливості культурної політики ЄС $\epsilon$ для нашої держави стратегічно важливими та які механізми мають бути прописаними в національній культурній стратегії для успішної інтеграції українського культурного простору в європейський контекст. Як об'єкт дослідження культурна політика Свропейського Союзу розглядається з різних позицій. Наприклад, вона може цікавити нашу державу як джерело цінного досвіду, який можна використовувати при аналізі перспектив та наслідків тих чи інших 
перетворень в гуманітарній сфері, може містити пропозиції вигідних для України умов інкорпорації до Свропи, стимулюючи водночас процеси внутрішнього розвитку галузі культури тощо.

Тут важливо враховувати і особливості культурної політики Свропейського Союзу, і власне українські інтереси, які полягають у створенні умов для розкриття творчого потенціалу кожної особистості, формуванні єдиного національного культурного простору як основи суспільної консолідації, ефективному використанні в інтересах суспільства творчого потенціалу українських митців, збереженні національної історико-культурної спадщини [11].

Основу соціально-економічного розвитку європейських країн на сучасному етапі складають культурні та креативні ресурси. Політика щодо інновацій в сфері культури та економіка знань, що базується на культурному потенціалі, забезпечують стабільний розвиток суспільства. Тож одним із пріоритетів для розвинутих держав $\epsilon$ інвестиції в розвиток інноваційного потенціалу культури, який сприяє становленню «креативної економіки», котра функціонує коштом нових ідей i здатна їх втілювати в конкурентні товари та послуги. Очевидною є актуальність державної підтримки інновацій в культурі як умови для становлення креативного середовища та соціально-економічного розвитку України.

Щодо інноваційної складової культурного розвитку слід уточнити, який зміст зазвичай вкладається в дане поняття. Так, інновації в сфері культури - це нові форми культурної діяльності, комунікації та управління культурним процесом, спрямовані на осмислення та використання історичного досвіду та практики людства XXI століття. В цілому інноваційну діяльність у галузі культури спрямовано на створення нового культурного продукту, або форм організації культурного процесу та креативних технологій $з$ метою задоволення культурних потреб сучасної людини та забезпечення сталого соціально-економічного розвитку суспільства.

Перед Україною стоїть завдання адаптації до європейських соціокультурних практик. Зокрема, це стосується сприяння розвитку «культурних індустрій» та «креативної економіки», оскільки зміцнення культурного потенціалу сприяє підвищенню інвестиційної привабливості України й закладає засади технологічного оновлення економіки.

Культурологічний вимір підписання Угоди про асоціацію з ЄС полягає в тому, що Україна стає повноцінним учасником загальноєвропейського культурного процесу. Але досягнення позитивних результатів на цьому шляху можливе лише за умови реформування в галузі культури. Зокрема, необхідне опанування новими формами управління культурним процесом, що потребує суттєвих змін у функціонуванні центральних i місцевих органів влади - їхня робота має відповідати прийнятим в ЄС нормам проектування та реалізації культурної політики.

Створення умов для інноваційного розвитку культури - наступний важливий наслідок реалізації Угоди про асоціацію. Українські заклади культури отримали можливість долучитися до реалізації загальноєвропейських програм розвитку. В тому числі за рахунок повноцінної участі в програмі «Креативна Європа». 
Важливою нині є розробка концептуальних засад розвитку «креативної економіки» в Україні та створення ефективної інноваційної інфраструктури. Для цього органи управління повинні розробити оптимальну модель комунікаційної та маркетингової підтримки інноваційної діяльності. Зокрема, потрібно налагодити «зворотній зв’язок» між митцями, аудиторією та менеджерами креативних технологій. Необхідно створювати прозорі процедури об'єктивної експертизи інноваційних культурних проектів, які претендують на підтримку 3 боку державного бюджету.

Особливої уваги потребує питання оптимізації й прозорості бюджетної підтримки закладів культури та проектів, які мають загальнонаціональне значення. Пріоритетом цієї підтримки має бути, з одного боку, збереження національних культурних традицій та національної самобутності, їх адаптація до сучасних форм культурної практики. 3 іншого - забезпечення зростання конкурентоздатності українського культурного продукту та практична імплементація тих частин Угоди про асоціацію з СС, котрі стосуються культурного обміну та розвитку культури.

У справі оптимізації фінансування сфери культури аналітики експертного середовища вбачають за потрібне знайти взаємодоповнення між державною підтримкою у формі бюджетної дотації та інвестиціями, котрі пов'язані з наданням визначених послуг, націлених на отримання прибутку. Ефективним, на їхню думку, буде запровадження елементів конкуренції між закладами культури в отриманні бюджетної підтримки, що стимулюватиме використання коштів за призначенням. Очевидно, що для повноцінної участі в проектах ЄС Україна потребує дієвої культурної стратегії 3 використанням європейського досвіду впровадження інновацій, змінивши в такий спосіб стару систему підходів до управління в галузі. А завдяки зміцненню культурного потенціалу та засвоєнню європейських практик Україна отримає можливість позбавитись нарешті від пострадянських стереотипів і пережитків, котрі й досі панують в українському соціумі [12].

На жаль, нові реалї виявили цілу низку проблем, які можуть стати на заваді нашому входженню в європейську спільноту як повноправного учасника культурних процесів та конкурентоспроможного гравця на ринку креативних індустрій.

У сучасних умовах, кожен із рівнів керування галуззю в Україні - чи то управління, відділ культури, або окремий заклад культури - живуть зазвичай своїм окремим замкненим життям, мало пов'язаним із діяльністю органів вищих та нижчих рівнів. Мабуть, це є однією з причин надзвичайно низької ефективності реалізації управлінських рішень, які, проходячи галузевими каналами, не впливають суттєво на змістовну діяльність закладів культури й знаходять своє відображення тільки в «паперотворчій» формі.

3 метою формування стратегії реформування культури Урядом було схвалено Довгострокову стратегію розвитку української культури до 2025 року - стратегію реформ, яка протягом 2015 року пройшла багатоетапне громадське обговорення, допрацьовувалася на секторальних та регіональних експертних зустрічах. Головні ii посили: треба відмовитися від патерналістської моделі стосунків 3 державою, перестати ділити культуру на «офіційну» та «неофіційну» й почати інвестувати в 
розвиток, а не стагнацію. Адже саме стагнацією можна назвати те, що відбувається впродовж десятиліть не тільки в галузі культури, але й у багатьох інших царинах врядування. На превеликий жаль, справжніх системних змін в країні за останні два роки так і не відбулося - корупція, кумівство, волюнтаризм та зневага до думок широкої громадськості замість справжніх реформ.

Власне, нову стратегію розвитку культури й спрямовано на те, щоб рухатися в бік сталості розвитку всього суспільства. Її збереження архаїзує державний апарат, все більше відриваючи його від реальності та поглиблюючи розлам між офіційною бюджетною i неофіційною недержавною культурою, послаблюючи їх обох i втрачаючи весь іхній потенціал [13; 14; 15]. Ось тому досвід Свропи - що його, можливо, непросто застосовувати на наших теренах, - може стати безцінним джерелом і практичних порад, і натхнення. Це допоможе Україні почати рух від старої командно-адміністративної системи контролю над творчістю до інклюзивної системи стимулювання творчості.

Європейська культурна спільнота завжди пропагувала переконання, що саме культура, а радше спільна культурна політика, має стати основою євроінтеграційних процесів. Утіленням цього дискурсу в реальне життя стало створення 1992 року альянсу, що отримав назву Culture Action Europe, CAE (Європейська культурна дія). Однією 3 його основних задач була адвокація інтересів культурних організацій, передовсім у такому дражливому питанні, як фінансування. Важливою особливістю є іï міжгалузевий характер: вона обстоює інтереси не тільки виконавських чи візуальних мистецтв, а усієї культурної царини загалом. Інші впливові міжнаціональні альянси переважно мають фахову природу. За час своєї роботи САЕ може похвалитися цілим рядом гучних адвокаційних кампаній.

Багаторічний досвід і Євросоюзу, і Великої Британії показує, що спі-льні зусилля культурних організацій часто можуть вплинути на ситуацію. Зокрема, на національному рівні британські культурні організації саме через зусилля альянсів давно навчилися говорити з владою іï мовою. Для цього довелося зібрати детальну статистику того, яким чином розвиток креативної економіки впливає на загальну економічну, а також і на соціальну ситуацію в країні. Рахували все, починаючи від кількості та вартості зайнятих готельних номерів під час культурних подій. Наразі назбиралося даних за понад десять років. Завдяки дуже активному лобіюванню інтересів сектора сьогодні культурні організації Великої Британії мають великий репутаційний ресурс, зауважує Клімена Хрістофоров, зараз мистецтво включене до соціальних та економічних стратегій країни, і це здобуток альянсів.

Пізніше САЕ приєдналася до Контактної групи громадянського суспільства ЕС. Її мета - підсилення впливу «третього сектора» на політиків Свропейського Союзу. Група є міжсекторальною та включає в себе впливові альянси громадських організацій у сферах прав людини, соціального захисту й охорони здоров'я. Представники Culture Action Europe регулярно виступають на парламентських слуханнях. Також волонтери платформи брали безпосередню участь у розробці «Порядку денного Свропи щодо культури», основного нормативного документа ЄС у галузі культури. 
Член виконавчого комітету САЕ також зауважує, що малим організаціям, а практично всі культурні організації можуть вважатися невеликими в масштабах країн, а тим більше СС, дуже важко проводити адвокаційні кампанії самостійно. Передовсім, через брак відповідних ресурсів. Але, попри будь-які зусилля, шансів на те, що таку кампанію помітять можновладці, дуже мало. У цьому сенсі залучення альянсів дає принципову перевагу. Це стосується і національного рівня. Поза цим, європейські мережі мають чітку спеціалізацію i практично не конкурують одна 3 одною, навпаки - охоче долучаються до спільних міжсекторальних проектів. Менші організації, що мають доступ до формування політик чи/або бюджетів лише через національні або європейські альянси, нерідко проводять активну адвокацію на регіональних рівнях, працюючи безпосередньо 3 виборцями.

Через стрімкий розвиток соціальних медіа в суспільства й активістів 3'являється більше можливостей ініціювати діалог із владою. Окрім соціальних медіа, на ефективність адвокаційних процесів впливає постійне зростання мобільності населення, передовсім, у межах Європи. Що стосується майбутнього адвокації, то фахівці переконані: роль альянсів лише зростатиме. Європейський вектор розвитку й збільшення мобільності вітчизняних культурних менеджерів допомагають українським організаціям дедалі активніше залучатися до європейських культурних процесів. Наразі в Україні розпочав роботу офic Creative Europe [16].

Сьогодні членство в мережах та альянсах допомагає українським активістам шукати партнерів за кордоном, відкриває нові можливості фінансування, але досвід адвокації можна - бодай теоретично - використати і на вітчизняних теренах, аби вибудувати новий дискурс спілкування із владою. Досі суспільний діалог у царині культури йде дуже непросто і тут $є$ чому повчитися в західних сусідів. Вивчаючи досвід СС, пов'язаний зі співпрацею культурних організацій, треба також відзначити, що їхні спільні зусилля насправді мають значний вплив на процес інтеграції всередині співдружності. Важливу роль у стосунках Україна ЄC відіграють спільні міжнародні культурні проекти, коли, приміром, представники від України мають можливість одночасно й досвід переймати в європейських колег, і виступати амбасадорами власної культури за кордоном.

Слід зазначити, що українським організаціям потрібно розбудовувати горизонтальну співпрацю також і в національних мережах, реформуючи стосунки 3 владою і вибудовуючи їх на засадах діалогу, а не ігнорування [16]. Для органів влади, пріоритетною залишається робота, пов'язана 3 реалізацією сучасних європейських культурних практик в Україні та забезпечення інтеграції національного культурного продукту в загальноєвропейський ландшафт [17, с. 2, 4-6].

Серйозною проблемою, яка, серед іншого, перешкоджає розвитку інноваційного потенціалу нашої держави є відсутність належної комунікативної бази, приміром спеціалізованого Інтернет-порталу інноваційних культурних проектів. Створення ресурсного центру, який би координував реалізацію інноваційних ініціатив у сфері «культурних індустрій» також є актуальним. На базі 
цієї структури можна було б організувати підготовку спеціалістів із реалізації інноваційних культурних проектів. Моніторинг таких проектів дозволив би визначати кращі 3 них для подальшої підтримки. До сфери компетенції такого центру, або агентства, повинно відноситися завдання щодо адаптації європейського досвіду «культурних індустрій» для умов України та налагодження міжнародного співробітництва 3 аналогічними структурами в СС.

Висновки. Особливості трансформаційних змін зумовлюють втрату стабільності і однозначності стратифікації суспільства. Поступово зникають межі між групами і верствами, виникають нові групи 3 невизначеним статусом. Звідси виникає криза довіри до дій владних структур, що загострює соціально-економічні процеси, які відбуваються в українському суспільстві.

Здійснення державою економічної функції у сфері інвестування має на меті створення сучасної системи регулювання, яка 6 підвищила інвестиційну привабливість економіки та забезпечила потужні мотивації нерезидентів щодо вкладення коштів. Особливо ефективним важелем успішного вирішення цього завдання може стати, податкова політика щодо закордонних інвестицій. 3 іншого боку, необхідно врахувати, що розвинені країни напрацювали значний досвід податкового стимулювання іноземного інвестування. Система оподаткування побудована таким чином, аби постійно заохочувати інвестора. Ефективність входження України у глобальну світову економічну систему робить актуальним необхідність підготовки фахівців нової якості, здатних послідовно відстоювати інтереси української держави в системі глобалізованого світу.

Можна визначити наступні пріоритети культурної державної політики в контексті загальної стратегї реформ в Україні. По-перше, це розвиток «людського потенціалу», якій полягає у формуванні креативних можливостей українського суспільства, здатності до збереження та передачі національних традицій майбутнім поколінням, можливості до впровадження інновацій в соціокультурній сфері. Тут важливим напрямом має стати підтримка конкурентоздатних інноваційних проектів, які націлено на опанування населенням культурних благ. По-друге, це забезпечення економічної самодостатності культурної сфери, бо впродовж усіх років державної незалежності вона фінансувалася за залишковим принципом. Бюджетна підтримка була багато в чому неадекватною тим завданням, які стояли перед культурою. Так, численні податкові та інші пільги, які схвалювали уряди впродовж останніх десятиріч, як правило, не торкалися роботи закладів культури. Необхідно, щоб культура отримувала інвестиції від держави відповідно тим масштабним завданням, які стоять перед нею. По-третє, це розвиток державних i громадських інститутів, які сприяють проектуванню та реалізації інноваційної культурної діяльності, зокрема забезпеченню просування інновацій у державному секторі управління. Це повинно відбуватися за коштом ліквідації адміністративних бар'єрів і здійснення культурної політики на засадах широкого громадського діалогу.

Для успішної інкорпорації української культури до європейського гуманітарного простору першочерговим завданням $€$ забезпечення іï репрезентативності на міжнародному рівні, що неможливо без реального наповнення культурного продукту власним національним змістом. Утім, 
культурний продукт не зможе зацікавити європейську аудиторію, якщо він не $є$ цікавим для української. Зацікавлення ж породжує практичний інтерес, створює перспективи партнерства та взаємних обмінів. Загалом, представлення української культури в світі можливе на кількох рівнях, зокрема це: створення відповідних інформаційно-культурних установ у європейських містах; підтримка державою окремих спільних культурно-мистецьких проектів, ініційованих громадським сектором; підтримка програм і проектів Свропейської Комісії та Ради Європи. На часі також проблема розробки чітких параметрів, за допомогою яких можна було б оцінювати ефективність культурної політики. Ці параметри мають визначати рівень залучення громадян до культурного процесу і вимірюватися кількісними та якісними показниками. В якісному вимірі це означає - здатність до освоєння сучасних культурних практик.

Потреба в нових цінностях суспільства, про яку останнім часом все більше говорять в Україні, стає визначальною для розвитку країни. Все очевиднішою стає також необхідність розробки і впровадження інклюзивної культурної політики, яка визначатиме як напрямки розвитку саме культурної царини, так і бачення розвитку країни в цілому в довгостроковій і середньостроковій перспективі. Така культурна політика створюватиме загальні рамки для трансформації суспільства на національному, регіональному та місцевому рівнях. Формування національної, причому заснованої не тільки на етнічній базі, ідентичності $є$ одним 3 найважливіших завдань у плані консолідації суспільства.

Насамперед у країні потрібно здійснити досить глибокі системні перетворення у різних сферах економічного, соціального, культурного та політичного життя, щоб міцніше утвердитися на шляху глокального розвитку. Цей етап необхідно пройти якомога енергійніше, щоб він був максимально стислим. Слід зберегти наступність реформ і глибоко усвідомити, що припущені недоліки та негативні риси нинішнього розвитку мають тимчасовий характер.

\section{Лimepamypa:}

1. Катаев С. ТРАНСФОРМАЦИЯ СУЧАСНОГО УКРАЇНСЬКОГО СУСПІЛЬСТВА: ПОСТМОДЕРНІСТСЬКИЙ КОНТЕКСТ / С.Катаев / Людина і політика. - 1999 - № 3 - С. 30.

2. Хобта С.В. ТЕОРІЯ МОДЕРНІЗАЦІЇ: ГЕНЕЗИС, ЕВОЛЮЦІЯ І СУЧАСНИЙ СТАН / С.В.Хобта / Грані. - 2006 - травень червень - С. 106.

3. Куценко О. СТАНОВЛЕНИЯ СОЦІАЛЬНИХ КЛАСІВ ЯК ВИЯВ САМООРГАНІЗАЦІЙНИХ ПРОЦЕСІВ У СУСПІЛЬСТВІ / 0. Куценко / Соціологія: теорія, методи, маркетинг. - 2002 - № 4 - С.123.

4. Гордієнко Б.С. МЕХАНІЗМИ АДАПТАЦІЇ СУЧАСНОЇ УКРАЇНСЬКОї ІНТЕЛІГЕНЦІЇ В ТРАНЗИТИВНОМУ СУСПІЛЬСТВІ / Б.С. Гордієнко / Методологія,теорія та практика соціологічного аналізу сучасного суспільства. Збірник наукових праць. - 2002 - С.291.

5. Бурлачук В. ОБРАЗ ВЛАДИ В СУЧАСНИХ ТЕОРІЯХ ГЛОБАЛІЗАЦІЇ / В.Бурлачук / Соціологія: теорія, методи, маркетинг. - 2009 - № 3 (липень - вересень ) - С.46 - 61.

6. Глушкова Л.В. ОСОБЛИВОСТІ ЗМІН СТРУКТУРИ УКРАЇНСЬКОГО СУСПІЛЬСТВА У ГЛОБАЛІЗАЦІЙНОМУ ПРОЦЕСІ / Л.В. ГЛУшкова // СОЦІОЛОГІЯ, № 4 (132). - квіт. - 2016. - c. 74-77

7. ІЛЬЯшенко В. ФІНАНСОВО-БЮДЖЕТНА СИСТЕМА УКРАЇНИ ТА ШЛЯХИ П̈Ї ТРАНСФОРМАЦІЇ / В. Ільяшенко // Економіка та держава : між нар. наук.-практ. журн. - 2005. № 5. - C. 38-42. 
8. В Мінкультури обговорили перспективи співпраці 3 Програмою «Культура і креативність» в рамках участі України у програмі «Креативна Європа» [Електронний ресурс]. Режим доступу: http://mincult.kmu.gov.ua/control/uk/publish/printable_article?art_id=245048621.

9. 5 МІФІВ ПРО УЧАСТЬ УКРАЇНИ У ПРОГРАМІ ЄС «КРЕАТИВНА ЄВРОПА» [Електронний ресурс]. - Режим доступу: http://www.eurointegration.com.ua/experts/2015/11/24/7041198/view_print/.

10. Culture for Development Indicators [Електронний ресурс]. - Режим доступу: http://www.unesco.org/new/en/culture/themes/cultural-diversity/culturalexpressions/programmes/culture-for-development-indicators/.

11. КУЛЬТУРНА ПОЛІТИКА УКРАЇНИ: НАЦІНАЛЬНА МОДЕЛЬ У ЄВРОПЕЙСЬКОМУ КОНТЕКСТІ [Електронний ресурс]. - Режим доступу: http://culture3.net/wpcontent/uploads/2013/10/Kul-_tura2012-6090f.pdf.

12. ТЕОРЕТИЧНІ ОСНОВИ ІННОВАЦІЙНИХ ПРОЦЕСІВ У ГАЛУЗІ КУЛЬТУРИ І МИСТЕЦТВ [Електронний ресурс]. - Режим доступу: http://osvita.ua/vnz/reports/-culture/10387/.

13. Сформовано стратегію реформ у сфері культури [Електронний ресурс]. - Режим доступу: http://prostir.museum/ua/post/36522.

14. Ботанова К. СТРАТЕГІЯ ДОВІРИ: ЯК ПЕРЕВЕРНУТИ СИСТЕМУ / КаТерИНа Ботанова [Електронний ресурс]. - Режим доступу: http://life.pravda.com.ua/culture/2016/02/16/208174/.

15. Островська-Люта О. РЕФОРМА КУЛЬТУРИ: НЕАДЕКВАТНІ РОМАНТИКИ ПРОТИ РАДЯНСЬКИХ АПАРАТНИКІВ / Олеся Островська-Люта [Електронний ресурс]. - Режим доступу: http://ukr.lb.ua/news/2016/02/09/327453_-reforma_kulturi_neadekvatni.html.

16. Демченко І. СПІЛЬНИЙ ГОЛОС: ЯК КУЛЬТУРНА СПІЛЬНОТА ЄС ДОСТУКУЄТЬСЯ ДО ВЛАДИ / Ілона Демченко [Електронний ресурс]. - Режим доступу: http://life.pravda.com.ua/culture/2016/01/26/207055/.

17. Шлепакова Т.Л. ПЕРЕФОРМАТУВАННЯ СИСТЕМИ УПРАВЛІННЯ В ГАЛУЗІ КУЛЬТУРИ ТА ЄВРОПЕЙСЬКИЙ ДОСВІД ІННОВАЦІЙНОГО РОЗВИТКУ: (огЛЯдова довідка за матеріалами преси, Інтернету та неопубл. документами за 2014-2016 рр.) / Нац. парлам. б-ка України, Інформ. центр 3 питань культури та мистецтва ; підгот. Т. Л. Шлепакова. - Київ 2016. -23 c.

\section{References:}

1. Kataev, S. (1999). Transformatsyia suchasnoho ukrainskoho suspilstva: postmodernistskyi kontekst [Transformation of modern Ukrainian society: postmodern context]. Liudyna i polityka - Man and politics, 3, 29-32 [in Ukrainian].

2. Khobta, S.V. (2006). Teoriia modernizatsii: henezys, evoliutsiia i suchasnyi stan [Theory of modernization: genesis, evolution and the current state]. Hrani - Grani, May-June, 100-106 [in Ukrainian].

3. Kutsenko, O. (2002). Stanovlenyia sotsialnykh klasiv yak vyiav samoorhanizatsiinykh protsesiv u suspilstvi [Formation of social classes as manifested by self-organizational processes in society]. Sotsiolohiia: teoriia, metody, marketynh - Sociology: theory, methods, marketing, 4, 123-137 [in Ukrainian].

4. Hordiienko, B.S. (2002). Mekhanizmy adaptatsii sovremennoy ukrainskoy intelligentsii V tranzitivnykh obshchestve [Mechanisms of adaptation of modern Ukrainian intelligence in transitive society]. Metodolohiia, teoriia ta praktyka sotsiolohichnoho analizu suchasnoho suspilstva Methodology, theory and practice of sociological analysis of modern society. (pp. 290-292). Kharkiv: Kharkivskyi natsionalnyi universytet imeni V. N. Karazina [in Russian].

5. Burlachuk, V. (2009). Obraz vlady v suchasnykh teoriiakh hlobalizatsii [Image of power in modern theories of globalization]. Sotsiolohiia: teoriia, metody, marketynh - Sociology: theory, methods, marketing, 3, 46-61 [in Ukrainian]. 
6. Hlushkova, L.V. (2016). Osoblyvosti zmin struktury ukrainskoho suspilstva u hlobalizatsiinomu protsesi [Peculiarities of changes in the structure of Ukrainian society in the globalization process]. Sotsiolohiia - Sociology, 4(132), 74-77 [in Ukrainian].

7. Iliashenko, V. (2005). Finansovo-biudzhetna systema Ukrainy ta shliakhy yii transformatsii [Financial and budget system of Ukraine and ways of its transformation]. Ekonomika ta derzhava Economy and State, 5, 38-42 [in Ukrainian].

8. V Minkultury obhovoryly perspektyvy spivpratsi z Prohramoiu «Kultura i kreatyvnist» v ramkakh uchasti Ukrainy u prohrami «Kreatyvna Yevropa» [The Ministry of Culture discussed the prospects of cooperation with the Program "Culture and Creativity" in the framework of Ukraine's participation in the program "Creative Europe"]. (2016). mincult.kmu.gov.ua. Retrieved from http://mincult.kmu.gov.ua/control/publish/article?art_id=245048621 [in Ukrainian].

9. Vitrenko, A. (2015). 5 mifiv pro uchast Ukrainy u prohrami YeS «Kreatyvna Yevropa» [5 myths about Ukraine's participation in "Creative Europe" EU program]. www.eurointegration.com.ua. Retrieved from https://www.eurointegration.com.ua/experts/2015/11/24/7041198/ [in Ukrainian].

10. Culture for Development Indicators. (n.d.). www.unesco.org. Retrieved from http://www.unesco.org/new/en/culture/themes/cultural-diversity/cultural-

expressions/programmes/culture-for-development-indicators/ [in English].

11. Zdioruk, S.I., Lytvynenko, O.M., Rozumna, O.P. (2012). Kulturna polityka Ukrainy: Natsionalna model u Yevropeiskomu konteksti [Cultural Policy of Ukraine: National Model in the European Context]. S. I. Zdioruk (Eds.). Kyiv: NISD. Retrieved from https://niss.gov.ua/sites/default/files/2013-02/Kultura_Zdioruk-beb1d.pdf [in Ukrainian].

12. Teoretychni osnovy innovatsiinykh protsesiv u haluzi kultury i mystetstv [Theoretical Fundamentals of Innovative Processes in the Field of Culture And Arts]. (2010). ru.osvita.ua. Retrieved from https://ru.osvita.ua/vnz/reports/culture/10387/ [in Ukrainian].

13. Nova kulturna polityka [New Culture Policy]. prostir.museum. (2016). Retrieved from http://prostir.museum/ua/post/36522 [in Ukrainian].

14. Botanova, K. (2016). Stratehiia doviry: yak perevernuty systemu [Trategy of Trust: How to Turn the System]. life.pravda.com.ua. Retrieved from https://life.pravda.com.ua/culture/2016/02/16/208174/ [in Ukrainian].

15. Ostrovska-Liuta, O. (2016). Reforma kultury: neadekvatni romantyky proty radianskykh aparatnykiv [Culture reform: inadequate romantics against soviet apparatus]. ukr.lb.ua. Retrieved from http://ukr.lb.ua/news/2016/02/09/327453_-reforma_kulturi_neadekvatni.html [in Ukrainian].

16. Demchenko, I. (2016). Spilnyi holos: yak kulturna spilnota yes dostukuietsia do vlady [Common voice: how the EU cultural community reaches power]. life.pravda.com.ua. Retrieved from http://life.pravda.com.ua/culture/2016/01/26/207055/ [in Ukrainian].

17. Shlepakova, T.L. (2016). Pereformatuvannia systemy upravlinnia $v$ haluzi kultury ta yevropeiskyi dosvid innovatsiinoho rozvytku [Reforming the Cultural Governance System and the European Experience of Innovative Development]. Kyiv [in Ukrainian]. 